\title{
PENGARUH GAJI, JAM KERJA FLEKSIBEL DAN STRES KERJA TERHADAP KINERJA KARYAWAN PADA PERUSAHAAN DI KOTA BATAM
}

\author{
Nonik Maifanda ${ }^{1)}$ \\ Muhammad Ramadhan Slamet ${ }^{2)}$ \\ Politeknik Negeri Batam \\ Jurusan Manajemen Bisnis, Program Studi Akuntansi Manajerial \\ Jl Ahmad Yani, Batam Centre, Batam 29461, Indonesia \\ E-mail: nonikmayfanda95@gmail.com ${ }^{1)}$ \\ ramadhanslamet@polibatam.ac.id ${ }^{2}$
}

\begin{abstract}
Abstrak
Penelitian ini bertujuan untuk menganalisis pengaruh gaji, jam kerja fleksibel dan stres kerja terhadap kinerja karyawan pada perusahaan yang berada di Kawasan Batamindo Industrial Park, Muka Kuning di Kota Batam pada tahun 2018. Gaji, jam kerja fleksibel dan stres kerja menjadi variabel independen, sedangkan variabel dependennya yaitu kinerja karyawan yang diukur dengan mengunakan skala likert dengan tipe skala interval (Hartono, 2015). Hipotesis yang diajukan pada penelitian ini adalah bahwa gaji, jam kerja fleksibel dan stres kerja berpengaruh terhadap kinerja karyawan. Metode pengumpulan data adalah dengan penyebaran kuesioner. Setelah kuesioner disebar ke 30 karyawan, selanjutnya dilakukan uji validitas dan uji reliabilitas untuk mengetahui kelayakan kuesioner. Populasi penelitian ini adalah 17 perusahaan yang yang berada di kawasan Batamindo Industrial Park, Muka Kuning di Kota Batam pada tahun 2018. Penentuan sampel menggunakan metode purposive sampling dan diperoleh sebanyak 100 koresponden. Pengolahan data dilakukan dengan menggunakan software SPSS v 25 dan melalui beberapa tahap yaitu analisis regresi linier berganda, uji statistik f, dan uji statistik t. Hasil analisis menunjukkan bahwa hipotesis pertama yaitu gaji tidak berpengaruh terhadap kinerja karyawan. Hipotesis kedua yaitu jam kerja fleksibel berpengaruh terhadap kinerja karyawan. Hipotesis ketiga yaitu stres kerja berpengaruh terhadap kinerja karyawan.
\end{abstract}

Kata kunci: Gaji, jam kerja fleksibel, stres kerja, kinerja karyawan

\begin{abstract}
This research aims to analyze the influence of salary, flexibility of working hours and job stress on employees' performance in companies throughout the Batamindo Industrial Park, Muka Kuning area in Batam City in 2018. Salary, flexibility of working hours and job stress are independent variables. While a dependent variable is employee performance that can be used using a Likert scale with an interval scale type (Hartono, 2015). The
\end{abstract}


hypothesis used in this research is shows salary, flexibility of working hours and job stress have influence on employee performance. Data collection method by distributing questionnaires. After the questionnaire was distributed to 30 people, validity and reliability testing was conducted to determine the feasibility of the questionnaire. The population of this research is 17 companies in the Batamindo. The sample was determined using purposive sampling method and obtained as many as 100 respondents. The data collected were analyzed in SPSS 25.0 Version and through several analyzes namely multiple linear regression, statistical test $f$, and statistical test $t$. The results show that the first hypothesis is that salary does not have influence on employee performance. The second hypothesis is the flexibility of working hours does have an influence on employee performance. Third hypothesis indicate job stress has an influence on employee performance.

Keywords: Salary, flexibility of working hours, job stress, employees 'performance 


\section{Pendahuluan}

Batam menjadi salah satu daerah di Indonesia yang dijadikan tempat investasi dan penanaman modal bagi pihak asing. Alasannya karena Batam merupakan Kota yang berada di jalur pelayaran internasional dan berbatasan langsung dengan

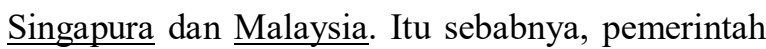
menetapkan Batam sebagai Kawasan Perdagangan Bebas atau Free Trade Zone (FTZ) beberapa tahun lalu, kemudian akan menjadi Kawasan Ekonomi Khusus (KEK). Faktor lain adalah karena gaji buruh di batam yang murah jika dibandingkan dengan dua negara tetangga tersebut.

Namun, dalam beberapa tahun ini Batam mengalami beberapa permasalahan serius seperti, adanya dualisme kelembagaan dan kewenangan antara PEMKO dan BP Batam, makin merosotnya daya saing Batam di Asia Pasifik serta di Tingkat Nasional yang menyebabkan semakin menurunnya investasi di Batam. Hal ini didukung pula dengan ketidakpastian atau kebijakan hukum di Batam yang selalu berganta-ganti serta iklim investasi. Hal ini mendukung terciptanya kebijakan pusat asal PMA untuk memindahkan pabrik mereka ke negara-negara yang memiliki iklim investasi lebih baik.

Berdasarkan data Dinas Ketenagakerjaan Kota Batam tercatat sudah 169 perusahaan gulung tikar sepanjang tahun 2015 sampai 2017. Hal ini membuat ekonomi Batam anjlok dari 5,4 pada 2016 menjadi di bawah 2 persen pada 2017. Jika pemerintah masih bersifat lambat dalam menentukan keputusan hal ini akan berdampak pada menurunnya kinerja karyawan tersebut. Karyawan yang seharusnya fokus dengan pekerjaan harus melakukan demo guna kenaikan gaji yang dipicu oleh kebutuhan sehari - hari yang semakin meningkat. Hal ini jelas akan membawa kerugian bagi dunia industri yang memikirkan aktivitas perusahaan akan terganggu akibat dari demonstrasi para karyawan tersebut apalagi sampai mogok kerja.

Berikut ini beberapa faktor yang dapat memengaruhi kinerja karyawan. Di antaranya adalah gaji, jam kerja fleksibel dan stres kerja. Menurut Mangkunegara (2013), kinerja adalah hasil kerja secara kualitas dan kuantitas yang dicapai oleh seorang karyawan dalam melaksanakan tugasnya sesuai dengan tanggung jawab yang diberikan kepadanya. Gaji adalah pembayaran atau penyerahan jasa yang dilakukan oleh karyawan yang umumnya dibayarkan secara tetap per bulan (Mulyadi, 2013). Penelitian Hameed et al., (2014) menyatakan bahwa gaji memiliki pengaruh positif terhadap kinerja karyawan. Namun hal tersebut berbanding berbalik dengan penelitian Gunawan dan Amalia (2015) menyatakan bahwa gaji memiliki pengaruh negatif terhadap kinerja karyawan.

Faktor kedua yang dapat memengaruhi kinerja karyawan adalah jam kerja fleksibel. Keuntungan yang dirasakan karyawan dalam jam kerja fleksibel adalah memberikan kebebasan karyawan untuk menentukan jam produktif atau terbaiknya dalam bekerja dengan suasana yang lebih nyaman. Namun, beberapa perusahaan di Batam masih meyakini bahwa jam kerja yang sama bisa membuat proses diskusi dalam mencari sebuah solusi bisa lebih cepat. Hal itu lebih sulit dilakukan jika jam kerja fleksibel diterapkan. Kekhawatiran lainnya, jam kerja fleksibel juga menyebabkan pengawasan pimpinan atas kinerja karyawan jadi terasa tak maksimal. Oleh karena itu, sistem jam kerja fleksibel memang tidak bisa langsung diterapkan di semua jenis perusahaan di Batam. Perlu kajian mendalam apakah budaya kerja di perusahaan cocok dengan sistem jam kerja fleksibel. Hal ini didukung pula oleh perbedaan hasil penelitian dari Abid dan Barech (2017) yang menyatakan bahwa jam kerja yang fleksibel memiliki pengaruh positif terhadap kinerja karyawan. Sedangkan penelitian Kattenbach et al., (2012) menyatakan bahwa jam kerja yang fleksibel memiliki pengaruh negatif terhadap kinerja karyawan.

Faktor ketiga yang dapat memengaruhi kinerja karyawan adalah stres kerja. Stres dapat diakibatkan karena kelelahan fisik, mental dan emosional yang disebabkan keterlibatan bekerja dalam waktu yang lama serta situasi yang tidak nyaman. Stres kerja 
yang dibiarkan begitu saja dapat membuat karyawan merasa tertekan, depresi, tidak ada motivasi dalam bekerja serta menyebabkan karyawan kinerja karyawan tidak optimal. Dampak terburuk jika karyawan tidak dapat menahan stres kerja maka karyawan tidak mampu lagi bekerja di perusahaan atau bahkan akan memutuskan untuk mengundurkan diri. Stres kerja karyawan juga dapat merugikan pihak perusahaan karena tidak imbangnya antara kinerja dengan biaya gaji yang dikeluarkan. Penelitian Sasono (2004) mengungkapkan bahwa stres kerja memiliki dampak yang negatif maupun positif terhadap kinerja karyawan. Hal ini terbukti dari perbedaan hasil penelitian yang telah dilakukan oleh Gharib et al., (2006) yang menyatakan bahwa stres kerja berhubungan positif pada kinerja pekerjaan mereka. Sebaliknya, Kotteeswari dan Sharief (2014) menyatakan bahwa stres kerja berhubungan negatif dengan kinerja.

Dengan latar belakang yang menarik inilah peneliti ingin mengetahui lebih lanjut bagaimana kinerja karyawan yang berada pada perusahaan di Kota Batam dengan mengadakan penelitian yang berjudul "PENGARUH GAJI, JAM KERJA FLEKSIBEL DAN STRES KERJA TERHADAP KINERJA KARYAWAN PADA PERUSAHAAN DI KOTA BATAM"

\section{Kerangka Teori \\ 2.1 Teori dan Penelitian Terdahulu}

\subsubsection{Teori Harapan}

Suatu pendekatan yang dapat digunakan untuk mengetahui apa yang dapat menggerakkan manusia adalah Expectancy Theory yang dinyatakan oleh Vroom (1964) atau yang disebut juga dengan teori Harapan. Terdapat tiga asumsi pokok Vroom dalam teori harapan. Asumsi-asumsi tersebut adalah sebagai berikut :

a. Setiap individu percaya bahwa bila ia memiliki perilaku dengan cara tertentu, ia akan memperoleh hal tertentu.

b. Setiap hasil mempunyai nilai, atau daya tarik bagi orang tertentu. Ini disebut valensi (valence) sebagai nilai yang orang berikan kepada suatu hasil yang diharapkan.

c. Setiap hasil berkaitan dengan suatu persepsi mengenai seberapa sulit mencapai hasil tersebut. Ini disebut harapan usaha (effort expectancy) sebagai kemungkinan bahwa usaha seseorang akan menghasilkan pencapaian suatu tujuan tertentu.

Sehubungan dengan hal tersebut, maka tampak jelas bahwa teori harapan dapat mendorong seseorang untuk memenuhi kebutuhannya. Hal ini wajar karena manusia selalu mempunyai kebutuhan yang berbeda-beda menurut status sosialnya di masyarakat. Sehingga unsur pembentuk harapannya berbeda-beda pula. Dengan memahami hal ini karyawan dapat menyusun perencanaan harapan yang baik untuk meningkatkan kinerjanya. Namun, harapan karyawan sering kali berbeda dengan harapan yang dikehendaki oleh perusahaan. Oleh karena itu, kemampuan perusahaan untuk mewujudkan harapan karyawan akan menjadi hal penting agar karyawan dapat meningkatkan kinerjanya, sehingga tujuan perusahaan akan tercapai. Dengan ini dapat disimpulkan bahwa gaji dan kinerja karyawan memiliki pengaruh satu sama lain. Karena gaji merupakan timbal balik atau motivasi yang diinginkan oleh karyawan atas kinerja yang telah dilakukan.

Penelitian Hameed et al., (2014) yang berjudul "Impact of compensation on employee performance (empirical evidence from banking sector of Pakistan)" yang bertujuan untuk mengukur dampak kompensasi terhadap kinerja karyawan. Dengan menggunakan metode kuesioner dirancang untuk mengumpulkan data mengenai faktor-faktor yang berkaitan dengan kompensasi seperti gaji dan kinerja karyawan. Data dikumpulkan dari berbagai bank di Punjabi selatan. Sekitar 45 bank dimasukkan untuk mengumpulkan data. Dengan mengambil sampel 200 pegawai bank yang dipilih secara acak. Data yang terkumpul dianalisis dalam versi SPSS 17.0. Berbagai teknik analisis dan deskriptif digunakan untuk menganalisis data. Analisis regresi \& deskriptif menunjukkan bahwa variabel independen gaji memiliki pengaruh yang signifikan terhadap kinerja 
karyawan. Hasil anova juga menunjukkan bahwa gaji pengaruh yang signifikan terhadap kinerja karyawan. Dari penelitian tersebut dapat disimpulkan dan ditemukan hasil bahwa gaji memiliki pengaruh yang signifikan positif terhadap kinerja karyawan.

Hasil ini berbanding berbalik dengan penelitian Penelitian Gunawan dan Amalia (2015) yang berjudul "Wages and employee performance: The quality of work life as moderator". Penelitian ini bertujuan untuk mengetahui pengaruh gaji terhadap kinerja karyawan yang dimoderasi oleh kualitas umur kerja. Jenis data yang digunakan adalah data primer berupa kuesioner. Pengambilan sampel dilakukan dengan mengumpulkan sampel acak sebanyak 100 karyawan di sebuah perusahaan manufaktur. Analisis data menggunakan regresi linier dan analisis regresi moderat. Hasil uji analisis regresi yang dimoderasi (MRA) menunjukkan interaksi perkalian dua atau lebih variabel bebas. Hasilnya menunjukkan dampak yang tidak signifikan antara pengaruh gaji dan kinerja karyawan. Hal ini disebabkan karena variabel independen lainnya yaitu kualitas kehidupan kerja memiliki pengaruh lebih kuat daripada motivasi ekstrinsik (gaji).

\subsubsection{Teori Peran}

Konflik peran yang dialami oleh pekerja dapat bersifat dua arah, masalah di pekerjaan yang berpengaruh terhadap kehidupan berkeluarga dan masalah keluarga yang dapat memengaruhi pekerjaan. Karyawan memainkan peran sosial di lingkungan pekerjaannya dan bagaimana ketegangan atau tekanan yang mereka alami dalam pekerjaan dapat berpengaruh secara negatif terhadap peran mereka di dalam kehidupan keluarganya (Greenhaus and Beutell 1985).

Dengan ini dapat dilihat bahwa jam kerja yang fleksibel merupakan salah satu solusi bagi karyawan untuk dapat menjalankan perannya di lingkungan pekerjaan dan lingkungan keluarga dengan seimbang. Dengan adanya jam kerja yang fleksibel karyawan dapat fokus dalam menjalankan tuntutan pekerjaannya, sehingga tuntutan peran sebagai pekerja dapat terpenuhi dengan baik.
Begitupun dengan tuntutan peran dalam keluarga dapat terpenuhi dengan baik pula karena pekerja memiliki waktu lebih luang untuk bersama keluarga. Waktu yang dibutuhkan untuk menjalankan salah satu tuntutan (keluarga atau pekerjaan) dapat mengurangi waktu untuk memenuhi kebutuhan tuntutan peran sebagai pekerja dan tuntutan peran dalam berumah tangga.

Penelitian Abid \& Barech (2017) yang berjudul "The impact of flexible working hours on the employees performance”. Tujuan penelitian ini adalah untuk memeriksa hipotesis nol bahwa ada hubungan antara jam kerja fleksibel dan kinerja karyawan. Dalam penelitian ini metodologi yang digunakan adalah campuran penelitian kuantitatif dan kualitatif. Data primer dikumpulkan melalui wawancara dan kuesioner. Sedangkan data sekunder dikumpulkan melalui internet, makalah penelitian dan artikel. Dengan menggunakan sampel acak sebanyak 200 karyawan di sebuah telekomunikasi / call center, membuktikan bahwa jam kerja yang fleksibel memiliki pengaruh yang signifikan positif terhadap kinerja karyawan. Membiarkan pekerja untuk memulai atau mengakhiri hari kerja lebih awal atau lambat dapat mengurangi stres kerja. Sebagian besar sampel menjawab bahwa mereka berorientasi pada gaji dan mereka siap bekerja kapanpun melawan gaji. Jadi dari penelitian ini, terbukti bahwa permintaan akan jam kerja yang fleksibel masih ada di Pakistan tapi perlu menggeneralisasi dan meningkatkan kesadaran tentang jam kerja fleksibel di antara berbagai tingkat manajemen.

Hal ini berbanding berbalik dengan penelitian Kattenbach et al., (2012) yang berjudul "flexible working times: effects on employees' exhaustion, work-nonwork conflict and job performance". Penelitian dilakukan dengan cara membagi kuesioner kepada 265 pelajar di 17 organisasi pelayanan seperti bank, asuransi, institusi penelitian, pelayanan perawatan, administrasi kotamadya dan departemen universitas di German. Kuesioner yang dapat di terima kembali yaitu sebanyak 167 kuesioner. Kuesioner terdiri dari 43 persen laki-laki dan 67 persen perempuan. Penelitian ini membuktikan bahwa jam 
kerja fleksibel memberikan pengaruh yang signifikan negatif terhadap variabel kinerja karyawan. Hasil penelitian ini membuktikan bahwa dengan adanya jam kerja fleksibel, maka kinerja karyawan pada suatu perusahaan akan menurun.

\subsubsection{Teori Atribusi}

Menurut Heider (1958) pencetus Teori atribusi, teori atribusi merupakan teori yang menjelaskan tentang perilaku seseorang. Teori ini mengacu pada bagaimana seseorang menjelaskan penyebab perilaku orang lain atau diri sendiri (Luthans, 1988). Dalam mengamati perilaku seseorang, dilihat dari apakah itu ditimbulkan secara internal atau eksternal. Disposition attribution atau penyebab internal mengacu pada 29 aspek perilaku individu, sesuatu yang ada dalam diri seseorang seperti sifat pribadi. Situational attribution atau penyebab eksternal mengacu pada lingkungan yang memengaruhi perilaku, seperti kondisi lingkungan kerja.

Penentu atribusi atau penyebab apakah individu atau situasi dipengaruhi oleh tiga faktor (Robbins, 1996) :

1. Konsensus (consensus) : perilaku yang ditunjukkan jika semua orang yang menghadapi situasi yang serupa menanggapi dengan cara yang sama.

2. Kekhususan (distincveness): perilaku yang ditunjukkan individu berlainan dalam situasi yang berlainan.

3. Konsistensi (consistency) : perilaku yang sama dalam tindakan seseorang dari waktu ke waktu. Sehubungan dengan hal ini maka dapat disimpulkan bahwa teori atribusi dapat menunjukkan perilaku seseorang dalam menghadapi situasi yang terjadi baik yang bersifat internal maupun eksternal. Dengan kata lain, karyawan harus dapat menjaga perilaku yang akan timbul dan dirasakan dalam mengatasi segala situasi yang terjadi seperti stres kerja yang dapat disebabkan oleh penyebab internal atau pribadi seperti kekhawatiran akan kondisi finansial, masalah-masalah yang bersangkutan dengan keluarga, fisik dan karakteristik kepribadian bawaan. Maupun stres kerja yang disebabkan oleh penyebab eksternal ataupun perusahaan seperti, beban kerja yang dirasakan terlalu berat, waktu kerja yang mendesak, lingkungan kerja yang tidak nyaman, hubungan antar karyawan yang tidak baik dan gaji yang dianggap terlalu rendah.

Penelitian Gharib et al., (2006) dalam penelitian yang berjudul "The impact of job stress on job performance: a case study on academic staff at dhofar university" menyatakan bahwa stres kerja tidak buruk sepanjang waktu, karena tingkat beban kerja menengah oleh staf akademik di DU berdampak positif pada kinerja pekerjaan mereka. Dengan mengambil sampel populasi penelitian yang terdiri dari semua staf akademik dari semua perguruan tinggi di Dhofar University. Survei ini disebarkan kepada semua anggota staf akademik di DU, yang 221 anggota mewakili seluruh populasi penelitian, jumlah kuesioner yang diterima yang valid untuk analisis adalah 102, sehingga tingkat tanggapan lebih dari $46 \%$ dari populasi penelitian. Hasil yang diperoleh dari kuesioner penelitian dianalisis dengan menggunakan analisis regresi berganda. Hasil menunjukkan bahwa tingkat stres kerja staf akademik sedang dan kadang-kadang rendah. Selain itu, ditemukan bahwa beban kerja memiliki efek statistik positif pada kinerja pekerjaan. Beberapa manajemen organisasi berpikir bahwa menetapkan tingkat stres yang wajar pada karyawan dapat mendorong kinerja karyawan (Zafar 2015). Muse et al., (2008) juga mendukung hubungan positif antara stres kerja dan kinerja pekerjaan.

Sebaliknya penelitian Kotteeswari \& Sharief (2014) yang berjudul "Job stress and its impact on employee performance a study with reference to employees working in BPOS" menyatakan bahwa stres kerja berpengaruh signifikan dengan kinerja. Dengan kata lain, semakin tinggi stres, akan menurunkan kinerja karyawan. Dengan menggunakan sampel sebanyak 100 karyawan yang bekerja di berbagai Industri proses bisnis outsourcing (BPO) di kota Chennai India. Data primer dikumpulkan dari karyawan tersebut. Data telah dikumpulkan dari berbagai sumber sekunder seperti jurnal, surat kabar, buku, situs web, konferensi, dll. Industri proses bisnis 
outsourcing (BPO) di India. Data yang dikumpulkan dianalisis dengan menggunakan uji chi-square. Berdasarkan data yang dikumpulkan analisis dan interpretasi ditemukan hasil penelitian bahwa Mayoritas karyawan setuju bahwa stres kerja memengaruhi kinerja mereka. Mereka tidak dapat berkonsentrasi pada pekerjaan mereka dengan benar. Mayoritas karyawan juga setuju bahwa mereka mengalami stres di tempat kerja terlepas dari jenis kelaminnya. Namun, karyawan dapat mencoba mengendalikan faktor stres kerja melalui beberapa latihan seperti yoga dan meditasi. Selain itu, Dukungan dari atasan juga dapat menyingkirkan stres kerja yang di alami karyawan dalam menjalankan pekerjaannya.

\subsection{Hipotesis penelitian}

$\mathrm{H}_{1}$ : Gaji berpengaruh terhadap kinerja karyawan

$\mathrm{H}_{2}$ : Jam kerja fleksibel berpengaruh terhadap kinerja karyawan

$\mathrm{H}_{3}$ : Stres kerja berpengaruh terhadap kinerja karyawan

\section{Metode Penelitian}

\subsection{Populasi dan Sampel}

Kriteria populasi data yang dipilih sebagai responden dalam penelitian ini adalah karyawan yang aktif bekerja pada 17 perusahaan di Batamindo Industrial Park, Muka Kuning di Batam tahun 2018. Dalam menentukan jumlah sampel yang akan digunakan dalam penelitian ini, peneliti menggunakan teknik penarikan jumlah sampel untuk populasi tidak terhingga atau tidak diketahui (Widiyanto 2008). Oleh karena itu, jumlah sampel dihitung dengan rumus sebagai adalah berikut:

$n=\frac{Z^{2}}{4(m o e)^{2}}=\frac{1,96}{4(0.1)^{2}}=96,04$ dibulatkan menjadi 97

Keterangan :

$n=$ Jumlah sampel

$\mathrm{Z}=$ Tingkat distribusi normal pada taraf signifikansi 97\% $(1,96)$

Moe $=$ Margin of error maksimal, adalah tingkat kesalahan maksimal pengambilan sampel yang masih bisa ditoleransi yaitu 10\%. Dari perhitungan penentuan jumlah sampel menggunakan rumus diatas maka sampel yang diambil yaitu sebanyak 97 responden. Namun, untuk mempermudah perhitungan data sampel digenapkan menjadi 100 responden.

\subsection{Metode Analisis Data}

Langkah-langkah yang dilakukan dalam penelitian ini: (1) menentukan variabel-variabel yang akan dimasukkan ke dalam tabel frekuensi; (2) editing, yaitu proses pengecekan dan penyesuaian data yang diperoleh; (3) coding, pemberian angka dari jawaban kuesioner dan kemudian dikelompokkan dalam kategori yang sama, yang bertujuan untuk menyederhanakan jawaban; dan (4) tabulating, yaitu menyajikan data-data yang telah diperoleh ke dalam tabel. Setelah itu, memasukkan rumus yang telah ditetapkan dalam operasional variabel ke microsoft excel lalu melakukan olah data menggunakan SPSS. Teknik pengolahan data pada penelitian ini menggunakan program SPSS versi 25.

Analisis data awal menggunakan analisis statistik deskriptif. Analisis deskriptif memberikan gambaran atau deskripsi suatu data yang dilihat dari nilai rata-rata (mean), standar deviasi, varian, maksimum, minimum, sum dan range. Selanjutnya, peneliti melakukan uji instrumen yaitu uji validitas dan uji reliabilitas. Uji validitas yaitu untuk mengukur sah atau valid tidaknya suatu kuesioner. Suatu kuesioner dikatakan valid jika pernyataan kuesioner mampu mengungkapkan sesuatu yang akan diukur oleh kuesioner tersebut (Ghozali, 2011). Validitas dalam penelitian menyatakan derajat ketepatan alat ukur penelitian terhadap isi atau arti sebenarnya yang diukur. Uji signifikansi dilakukan dengan membandingkan nilai $r$ hitung dengan $r$ tabel, jika $r$ hitung $>r$ tabel maka variabel tersebut dinyatakan valid, begitu sebaliknya(Ghozali, 2011).

Uji Reliabilitas yaitu suatu angka indeks yang menunjukkan konsistensi suatu alat pengukur di dalam mengukur gejala yang sama. Setiap alat pengukur seharusnya memiliki kemampuan untuk memberikan hasil pengukuran yang konsisten. 
Instrumen yang reliabel adalah instrumen yang bilamana dicobakan secara berulang-ulang pada kelompok yang sama akan menghasilkan data yang sama akan menghasilkan data yang sama dengan asumsi tidak terdapat perubahan psikologis terhadap responden. Pengukuran reliabilitas dilakukan dengan uji statistik Cronbach Alpha. Suatu variabel dikatakan reliabel apabila memberikan nilai Cronbach Alpha > 0,60 (Ghozali, 2011).

Uji asumsi klasik adalah pengujian data dalam penelitian untuk mengetahui kondisi data yang digunakan dalam suatu penelitian. Beberapa pengujian yang harus dilakukan dalam penelitian ini adalah uji normalitas, uji multikolineritas, uji heteroskedastisitas dan uji Hipotesis. Uji normalitas yaitu untuk melihat apakah nilai residual terdistribusi normal atau tidak. Model regresi yang baik adalah memiliki nilai residual yang terdistribusi normal, sehingga uji normalitas bukan dilakukan pada masing-masing variabel tetapi pada nilai residualnya. Uji normalitas bertujuan untuk menguji salah satu asumsi dasar analisis regresi berganda, yaitu variabel - variabel independen dan dependen harus berdistribusi normal atau mendekati normal (Ghozali, 2011).

Uji multikolineritas bertujuan untuk menguji ada atau tidaknya korelasi antara variabel bebas. Model regresi yang baik seharusnya tidak terjadi korelasi antara variabel bebasnya. Multikolinieritas dapat dilihat dari tolerance dan vaiance inflation factor (VIF). Jika nilai tolerance $<0,01$ dan nilai VIF $>10$ maka model regresi bebas dari multikolinieritas (Ghozali, 2011). Uji heteroskedastisitas Bertujuan untuk menguji apakah dalam suatu model regresi terjadi perbedaan varian residual suatu periode pengamatan ke pengamatan lain. Jika varian dari residual satu pengamatan ke pengamatan lain tetap, maka disebut homoskedastisitas. Model regresi yang baik adalah yang homoskedastisitas atau tidak terjadi heteroskedastisitas. Jika nilai signifikansi antara variable independen dengan absolut residual lebih dari 0,05 maka tidak terjadi masalah homoskedastisitas (Ghozali, 2006).
Penelitian ini menggunakan pengujian hipotesis dengan analisis regresi linier berganda untuk mengetahui arah hubungan antara variabel independen dengan variabel dependen serta dikatakan regresi linier berganda karena setiap estimasi atas nilai diharapkan mengalami peningkatan atau penurunan mengikuti garis lurus.

Rumus analisis regresi linier berganda adalah (Ghozali, 2012):

$\mathrm{KK}=\mathrm{a}+\mathrm{b} 1 \mathrm{G}+\mathrm{b} 2 \mathrm{JKF}+\mathrm{b} 3 \mathrm{SK}$

Keterangan rumus:

$\begin{array}{ll}\text { KK } & \text { : Kinerja Karyawan } \\ \text { a } & : \text { konstanta } \\ \text { G } & : \text { Gaji } \\ \text { JKF } & \text { : Jam Kerja Fleksibel } \\ \text { SK } & \text { : Stres Kerja } \\ \text { b1+b2+b3 }: \text { Koefisien Regresi }\end{array}$

\subsection{Karakteristik Data}

\section{Hasil}

Tabel 1 Karakteristik Data

\begin{tabular}{|l|c|}
\hline \multicolumn{1}{|c|}{ Keterangan } & Jumlah \\
\hline Kuesioner yang disebarkan & 153 \\
\hline Kuesioner yang tidak kembali & 28 \\
\hline Kuesioner yang kembali & 125 \\
\hline $\begin{array}{l}\text { Kuesioner yang tidak sesuai dengan } \\
\text { kriteria penelian }\end{array}$ & 25 \\
\hline Total sampel yang digunakan & $\mathbf{1 0 0}$ \\
\hline
\end{tabular}

Sumber: Data diolah sendiri

Berdasarkan tabel 1 dari 153 kuesioner yang disebarkan, kuesioner kembali hanya berjumlah 125 . Kuesioner yang tidak kembali berjumlah 28. Kuesioner yang tidak sesuai dengan kriteria penelitian berjumlah 25. Dengan ini, peneliti mendapatkan kuesioner berjumlah 100 responden yang telah ditetapkan.

Setiap responden yang telah mengisi kuesioner diidentifikasi berdasarkan jenis kelamin, status perkawinan, kualifikasi pendidikan terakhir, jumlah penghasilan dan lama bekerja. Identifikasi ini bertujuan untuk mengetahui karakteristik secara umum para responden. 100 responden yang digunakan dalam penelitian ini, responden wanita 
lebih dominan dengan persentase sebesar $88.0 \%$ jika dibandingkan dengan responden pria dengan persentase sebesar $12.0 \%$. Dilihat dari sisi status perkawinan, responden dengan status belum menikah mendominasi dengan persentase sebesar $91.0 \%$. Para responden mayoritas berada di kualifikasi pendidikan, yaitu SMA/SMK dengan persentase terbesar yaitu $71.0 \%$ dengan jumlah penghasilan lebih dominan berkisar antara 3-6 juta perbulan dengan persentase sebesar $76.0 \%$ dengan masa bekerja antara 2-6 tahun dengan persentase sebesar $51.0 \%$.

\subsection{Analisis Deskripsi Variabel}

Analisis deskripsi digunakan sebagai analisa terhadap variable gaji, jam kerja fleksibel dan kinerja karyawan yang diperoleh berdasarkan hasil jawaban responden atas pernyataan kuesioner pada masing-masing indikator variabel penelitian. Hasil distribusi jawaban responden dari masing-masing variabel tersebut akan dijelaskan dalam tabel Berikut:

Tabel 2 Distribusi Frekuensi Jawaban

Responden Terhadap Variabel Gaji

\begin{tabular}{|c|c|c|c|c|c|c|c|c|c|c|c|}
\hline \multicolumn{10}{|c|}{ Gaji } \\
\hline \multirow{2}{*}{$\begin{array}{c}\text { Ite } \\
\mathrm{m}\end{array}$} & \multicolumn{10}{|c|}{ Frekuensi Jawaban Responden } & \multicolumn{1}{c|}{$\begin{array}{c}\text { To } \\
\text { tal }\end{array}$} \\
\cline { 2 - 12 } & $\mathrm{S}$ & & $\mathrm{T}$ & & & & & & $\mathrm{S}$ & & \\
& $\mathrm{T}$ & & $\mathrm{T}$ & & & & & & & \\
& $\mathrm{S}$ & $\%$ & $\mathrm{~S}$ & $\%$ & $\mathrm{~N}$ & $\%$ & $\mathrm{~S}$ & $\%$ & $\mathrm{~S}$ & $\%$ & \\
\hline $\mathrm{X} 1$ & & & & & 1 & 1 & 6 & 6 & 1 & 1 & 10 \\
.1 & 0 & 0 & 2 & 2 & 8 & 8 & 7 & 7 & 3 & 3 & 0 \\
\hline $\mathrm{X} 1$ & & & & & 3 & 3 & 4 & 4 & 1 & 1 & 10 \\
.2 & 8 & 8 & 9 & 9 & 2 & 2 & 0 & 0 & 1 & 1 & 0 \\
\hline $\mathrm{X} 1$ & & & 1 & 1 & 2 & 2 & 4 & 4 & 1 & 1 & 10 \\
.3 & 0 & 0 & 7 & 7 & 8 & 8 & 0 & 0 & 5 & 5 & 0 \\
\hline $\mathrm{X} 1$ & & & 2 & 2 & 2 & 2 & 3 & 3 & & & 10 \\
.4 & 8 & 8 & 9 & 9 & 6 & 6 & 0 & 0 & 7 & 7 & 0 \\
\hline $\mathrm{X} 1$ & & & 1 & 1 & 2 & 2 & 5 & 5 & 1 & 1 & 10 \\
.5 & 1 & 1 & 3 & 3 & 3 & 3 & 3 & 3 & 0 & 0 & 0 \\
\hline
\end{tabular}

Sumber: Hasil Output SPSS 25

Berdasarkan tabel 2 diatas, variabel gaji yang diukur dengan 5 indikator, dapat diketahui bahwa secara umum responden mempersepsikan bahwa gaji yang diterima baik. Tabel tersebut menjelaskan jika jawaban para responden yang cenderung setuju dengan pernyataan mengenai gaji yang diterimanya.

Tabel 3 Distribusi Frekuensi Jawaban

Responden Terhadap Variabel Jam Kerja Fleksibel

\begin{tabular}{|c|c|c|c|c|c|c|c|c|c|c|c|}
\hline \multicolumn{12}{|c|}{ Jam kerja fleksibel } \\
\hline \multirow{2}{*}{$\begin{array}{l}\text { Ite } \\
\text { m }\end{array}$} & \multicolumn{10}{|c|}{ Frekuensi Jawaban Responden } & $\begin{array}{l}\text { To } \\
\text { tal }\end{array}$ \\
\hline & $\begin{array}{l}\mathrm{S} \\
\mathrm{T} \\
\mathrm{S}\end{array}$ & $\%$ & $\begin{array}{l}\mathrm{T} \\
\mathrm{S}\end{array}$ & $\%$ & $\mathrm{~N}$ & $\%$ & $\mathrm{~S}$ & $\%$ & $\begin{array}{l}\mathrm{S} \\
\mathrm{S}\end{array}$ & $\%$ & \\
\hline $\mathrm{X} 2$ & & & 1 & 1 & 2 & 2 & 4 & 4 & 1 & 1 & 10 \\
\hline .1 & 1 & 1 & 0 & 0 & 7 & 7 & 5 & 5 & 7 & 7 & 0 \\
\hline $\mathrm{X} 2$ & & & & & 1 & 1 & 3 & 3 & 4 & 4 & 10 \\
\hline .2 & 2 & 2 & 4 & 4 & 5 & 5 & 5 & 5 & 4 & 4 & 0 \\
\hline $\mathrm{X} 2$ & & & & & 1 & 1 & 4 & 4 & 3 & 3 & 10 \\
\hline .3 & 0 & 0 & 6 & 6 & 6 & 6 & 2 & 2 & 6 & 6 & 0 \\
\hline $\mathrm{X} 2$ & & & 1 & 1 & 4 & 4 & 3 & 3 & 1 & 1 & 10 \\
\hline .4 & 2 & 2 & 2 & 2 & 1 & 1 & 2 & 2 & 3 & 3 & 0 \\
\hline $\mathrm{X} 2$ & & & & & & & 4 & 4 & 4 & 4 & 10 \\
\hline .5 & 1 & 1 & 2 & 2 & 7 & 7 & 7 & 7 & 3 & 3 & 0 \\
\hline
\end{tabular}

Sumber: Hasil Output SPSS 25

Berdasarkan table 3 diatas, variable jam kerja fleksibel yang diukur dengan 5 indikator, dapat diketahui bahwa secara umum responden mempersepsikan bahwa jam kerja fleksibel dibutuhkan dalam bekerja. Tabel tersebut menjelaskan jika jawaban para responden yang cenderung setuju dengan pernyataan mengenai adanya penerapan jam kerja fleksibel di perusahaan.

Tabel 4 Distribusi Frekuensi Jawaban

Responden Terhadap Variabel Stres Kerja

\begin{tabular}{|c|c|c|c|c|c|c|c|c|c|c|c|}
\hline \multicolumn{12}{|c|}{ Stres Kerja } \\
\hline \multirow{2}{*}{$\begin{array}{l}\text { Ite } \\
\text { m }\end{array}$} & \multicolumn{10}{|c|}{ Frekuensi Jawaban Responden } & $\begin{array}{c}\text { Tot } \\
\text { al }\end{array}$ \\
\hline & $\begin{array}{l}\mathrm{T} \\
\mathrm{T} \\
\mathrm{S}\end{array}$ & $\%$ & $\begin{array}{l}\mathrm{T} \\
\mathrm{S} \\
\end{array}$ & $\%$ & $\mathrm{~N}$ & $\%$ & $\mathrm{~S}$ & $\%$ & $\begin{array}{l}S \\
S\end{array}$ & $\%$ & \\
\hline $\mathrm{X} 3$ & & & & & 2 & 2 & 4 & 4 & 2 & 2 & 10 \\
\hline .1 & 2 & 2 & 7 & 7 & 2 & 2 & 5 & 5 & 4 & 4 & 0 \\
\hline $\mathrm{X} 3$ & & & & & & & 6 & 6 & 1 & 1 & 10 \\
\hline .2 & 2 & 2 & 3 & 3 & 9 & 9 & 7 & 7 & 9 & 9 & 0 \\
\hline $\mathrm{X} 3$ & & & & & 1 & 1 & 5 & 5 & 3 & 3 & 10 \\
\hline .3 & 0 & 0 & 2 & 2 & 1 & 1 & 7 & 7 & 0 & 0 & 0 \\
\hline $\mathrm{X} 3$ & & & & & & & 5 & 5 & 4 & 4 & 10 \\
\hline .4 & 1 & 1 & 0 & 0 & 6 & 6 & 0 & 0 & 3 & 3 & 0 \\
\hline $\mathrm{X} 3$ & & & & & & & 5 & 5 & 4 & 4 & 10 \\
\hline .5 & 1 & 1 & 0 & 0 & 6 & 6 & 0 & 0 & 7 & 7 & 0 \\
\hline
\end{tabular}

Sumber: Hasil Output SPSS 25 
Berdasarkan table 4 diatas, variable stres kerja yang diukur dengan 5 indikator, dapat diketahui bahwa secara umum responden mempersepsikan bahwa stres kerja terjadi dilingkungan pekerjaan. Tabel tersebut menjelaskan jika jawaban para responden yang cenderung setuju dengan pernyataan mengenai stres kerja yang dirasakan selama ini.

Tabel 6 Distribusi Frekuensi Jawaban

Responden Terhadap Variabel Kinerja karyawan

\begin{tabular}{|c|c|c|c|c|c|c|c|c|c|c|c|}
\hline \multicolumn{10}{|c|}{ Kinerja Karyawan } \\
\hline \multirow{2}{*}{$\begin{array}{c}\text { Ite } \\
\mathrm{m}\end{array}$} & \multicolumn{10}{|c|}{ Frekuensi Jawaban Responden } & \multicolumn{1}{c|}{$\begin{array}{c}\text { To } \\
\text { tal }\end{array}$} \\
\cline { 2 - 12 } & $\mathrm{S}$ & & $\mathrm{T}$ & & & & & & $\mathrm{S}$ & & \\
& $\mathrm{T}$ & & $\mathrm{T}$ & & & & & & \\
& $\mathrm{S}$ & $\%$ & $\mathrm{~S}$ & $\%$ & $\mathrm{~N}$ & $\%$ & $\mathrm{~S}$ & $\%$ & $\mathrm{~S}$ & $\%$ & \\
\hline $\mathrm{Y} 1$ & & & 1 & 1 & 1 & 1 & 6 & 6 & 1 & 1 & 10 \\
.1 & 7 & 7 & 0 & 0 & 0 & 0 & 2 & 2 & 1 & 1 & 0 \\
\hline $\mathrm{Y} 1$ & & & & & 2 & 2 & 5 & 5 & 1 & 1 & 10 \\
.2 & 2 & 2 & 9 & 9 & 0 & 0 & 1 & 1 & 8 & 8 & 0 \\
\hline $\mathrm{Y} 1$ & & 1 & 2 & 2 & 3 & 3 & 2 & 2 & & & 10 \\
.3 & 11 & 1 & 5 & 5 & 9 & 9 & 4 & 4 & 1 & 1 & 0 \\
\hline $\mathrm{Y} 1$ & & & 2 & 2 & 2 & 2 & 4 & 4 & & & 10 \\
.4 & 6 & 6 & 6 & 6 & 0 & 0 & 3 & 3 & 5 & 5 & 0 \\
\hline $\mathrm{Y} 1$ & & & 2 & 2 & 1 & 1 & 5 & 5 & & & 10 \\
.5 & 0 & 0 & 0 & 0 & 5 & 5 & 7 & 7 & 8 & 8 & 0 \\
\hline
\end{tabular}

Sumber: Hasil Output SPSS 25

Berdasarkan table 6 diatas, variabel kinerja karyawan yang diukur dengan 5 indikator, dapat diketahui bahwa secara umum responden mempersepsikan bahwa mereka memiliki memberikan kinerja yang baik. Tabel tersebut menjelaskan jika jawaban para responden yang cenderung setuju dengan pernyataan mengenai penilaian kinerja mereka selama bekerja.

\subsection{Pengujian Instrumen}

\subsubsection{Uji Validitas}

Uji validitas digunakan untuk mengukur valid tidaknya suatu kuesioner. Suatu kuesioner dikatakan valid jika pertanyaannya mampu mengungkapkan sesuatu yang dapat diukur. Pengujian dilakukan dengan mencari nilai korelasi antara skor masing-masing item pertanyaan dengan total skor masing-masing dimensinya. Pertanyaan kuesioner dinyatakan valid jika $r$ hitung $>r$ table
(Ghozali, 2012). Hasil uji validitas ditampilkan pada tabel 7 berikut:

Tabel 7 Uji Validitas

\begin{tabular}{|c|c|c|c|c|}
\hline \multirow{2}{*}{ Variabel } & $\begin{array}{c}\text { Validita } \\
\mathrm{s}\end{array}$ & & & \\
\hline & Item & $\begin{array}{c}\mathrm{r} \\
\text { hitung }\end{array}$ & $\mathrm{r}$ tabel & $\underset{n}{\text { Kesimpula }}$ \\
\hline \multirow{5}{*}{ Gaji } & X1.1 & $\begin{array}{c}.333 * \\
*\end{array}$ & $\begin{array}{c}0.194 \\
6\end{array}$ & Valid \\
\hline & X1.2 & $\begin{array}{c}.614 * \\
*\end{array}$ & $\begin{array}{c}0.194 \\
6\end{array}$ & Valid \\
\hline & X1.3 & $\begin{array}{c}.562 * \\
*\end{array}$ & $\begin{array}{c}0.194 \\
6\end{array}$ & Valid \\
\hline & X1.4 & $\begin{array}{c}.648 * \\
*\end{array}$ & $\begin{array}{c}0.194 \\
6\end{array}$ & Valid \\
\hline & X1.5 & $\begin{array}{c}.415^{*} \\
*\end{array}$ & $\begin{array}{c}0.194 \\
6\end{array}$ & Valid \\
\hline \multirow{5}{*}{$\begin{array}{c}\text { Jam } \\
\text { kerja } \\
\text { fleksibel }\end{array}$} & X2.1 & $\begin{array}{c}.540 * \\
*\end{array}$ & $\begin{array}{c}0.194 \\
6\end{array}$ & Valid \\
\hline & $\mathrm{X} 2.2$ & $\begin{array}{c}.598 * \\
*\end{array}$ & $\begin{array}{c}0.194 \\
6\end{array}$ & Valid \\
\hline & $\mathrm{X} 2.3$ & $\begin{array}{c}.633^{*} \\
*\end{array}$ & $\begin{array}{c}0.194 \\
6\end{array}$ & Valid \\
\hline & X2.4 & $\begin{array}{c}.306^{*} \\
*\end{array}$ & $\begin{array}{c}0.194 \\
6 \\
\end{array}$ & Valid \\
\hline & X2.5 & $\begin{array}{c}.573 * \\
*\end{array}$ & $\begin{array}{c}0.194 \\
6\end{array}$ & Valid \\
\hline \multirow{5}{*}{$\begin{array}{l}\text { Stres } \\
\text { kerja }\end{array}$} & X3.1 & $\begin{array}{c}.546^{*} \\
*\end{array}$ & $\begin{array}{c}0.194 \\
6\end{array}$ & Valid \\
\hline & X3.2 & $\begin{array}{c}.456^{*} \\
*\end{array}$ & $\begin{array}{c}0.194 \\
6\end{array}$ & Valid \\
\hline & X3.3 & $\begin{array}{c}.479 * \\
*\end{array}$ & $\begin{array}{c}0.194 \\
6\end{array}$ & Valid \\
\hline & X3.4 & $\begin{array}{c}.532 * \\
*\end{array}$ & $\begin{array}{c}0.194 \\
6\end{array}$ & Valid \\
\hline & X3.5 & $\begin{array}{c}.397 * \\
*\end{array}$ & $\begin{array}{c}0.194 \\
6\end{array}$ & Valid \\
\hline \multirow{5}{*}{$\begin{array}{c}\text { Kinerja } \\
\text { karyawa } \\
\mathrm{n}\end{array}$} & Y1.1 & $\begin{array}{c}.761 * \\
*\end{array}$ & $\begin{array}{c}0.194 \\
6\end{array}$ & Valid \\
\hline & Y1.2 & $\begin{array}{c}.779 * \\
*\end{array}$ & $\begin{array}{c}0.194 \\
6\end{array}$ & Valid \\
\hline & Y1.3 & $\begin{array}{c}.680^{*} \\
*\end{array}$ & $\begin{array}{c}0.194 \\
6\end{array}$ & Valid \\
\hline & Y1.4 & $\begin{array}{c}.804 * \\
*\end{array}$ & $\begin{array}{c}0.194 \\
6\end{array}$ & Valid \\
\hline & Y1.5 & $\begin{array}{c}.779 * \\
*\end{array}$ & $\begin{array}{c}0.194 \\
6\end{array}$ & Valid \\
\hline
\end{tabular}

Sumber : Hasil Output SPSS 25.

Berdasarkan table 7 diatas, dapat dilihat jika setiap indikator pertanyaan yang digunakan mempunyai nilai $r$ hitung yang lebih besar dari $r$ table, yang berarti indikator pertanyaan dari masing-masing variable yang digunakan dalam 
penelitian ini dinyatakan valid untuk digunakan sebagai alat untuk variable.

\subsubsection{Uji Reliabilitas}

Tabel 8 Uji Reliabilitas

\begin{tabular}{|l|c|c|c|}
\hline \multirow{2}{*}{ Variabel } & \multicolumn{3}{|c|}{ Realibilitas } \\
\cline { 2 - 4 } & $\begin{array}{c}\text { Alpha } \\
\text { cronbac } \\
\mathrm{h}\end{array}$ & $\begin{array}{c}\text { Cut off } \\
\text { Alpha } \\
\text { Cronba } \\
\text { ch }\end{array}$ & $\begin{array}{c}\text { Kesimpu } \\
\text { lan }\end{array}$ \\
\hline Gaji kerja & 0.868 & 0.60 & Reliabel \\
\hline $\begin{array}{l}\text { Jam } \\
\text { fleksibel }\end{array}$ & 0.735 & 0.60 & Reliabel \\
\hline Stres kerja & 0.742 & 0.60 & Reliabel \\
\hline $\begin{array}{l}\text { Kinerja } \\
\text { karyawan }\end{array}$ & 0.817 & 0.60 & Reliabel \\
\hline
\end{tabular}

Sumber : Hasil Output SPSS 25

Berdasarkan tabel 8 diatas, semua variabel dalam penelitian memiliki nilai Alpha Cronbach lebih besar dari 0,60, maka dapat disimpulkan bahwa semua variable yang digunakan dalam pelitian ini adalah reliabel.

\subsection{Uji Asumsi Klasik \\ 4.4.1. Uji Normalitas}

Tabel 9 Hasil Uji Normalitas

\begin{tabular}{|l|c|c|c|}
\hline & $\begin{array}{c}\text { Unstanda } \\
\text { rdized } \\
\text { Residual } \\
\text { X1 }\end{array}$ & $\begin{array}{c}\text { Unstanda } \\
\text { rdized } \\
\text { Residual } \\
\text { X2 }\end{array}$ & $\begin{array}{c}\text { Unstanda } \\
\text { rdized } \\
\text { Residual } \\
\text { X3 }\end{array}$ \\
\hline $\begin{array}{l}\text { Kolmogorov- } \\
\text { Smirnov Z }\end{array}$ & 0.104 & 0.109 & 0.121 \\
\hline $\begin{array}{l}\text { Asymp.Sig. } \\
\text { (2-tailed) }\end{array}$ & 0.051 & 0.060 & 0.070 \\
\hline
\end{tabular}

Sumber: Hasil Ouput SPSS 25

Berdasarkan tabel 9, besarnya nilai signifikansi tiga variabel lebih besar dari 0,05, sehingga dapat disimpulkan bahwa data residual telah berdistribusi normal.

\subsection{2 . Uji Multikolinieritas}

Tabel 10 Hasil Uji Multikolinieritas

\begin{tabular}{|c|c|c|}
\hline Variabel & Tolerance & VIF \\
\hline Gaji & 0.981 & 1.019 \\
\hline Jam kerja fleksibel & 0.939 & 1.065 \\
\hline Stres kerja & 0.929 & 1.076 \\
\hline
\end{tabular}

Sumber: Hasil Output SPSS 25

Berdasarkan tabel 10 diatas, setiap variable mempunyai nilai $\mathrm{VIF}<10$ dan tolerance $>0,10$, maka dapat disimpulkan bahwa tidak terjadi multikolinieritas antar variable bebas dalam model regresi ini.

\subsubsection{Uji Heteroskedastisitas}

Tabel 11 Hasil Uji Heteroskedastisitas

\begin{tabular}{|c|c|c|}
\hline Variabel & T hitung & Sig. \\
\hline Gaji & 1.208 & 0.230 \\
\hline $\begin{array}{c}\text { Jam kerja } \\
\text { fleksibel }\end{array}$ & 2.590 & 0.611 \\
\hline Stres kerja & 0.450 & 0.654 \\
\hline
\end{tabular}

Sumber: Hasil Output SPSS 25

Berdasarkan table 11 diatas, tidak terdapat satupun variabel independen yang signifikan memengaruhi variabel dependen nilai absolut residual. Hal ini terlihat dari nilai signifikansi yang lebih besar dari 0,05. Maka dapat disimpulkan jika model regresi tidak mengandung adanya heteroskedastisitas.

\subsubsection{Pengujian Hipotesis}

Tabel 12 Hasil Uji Analisis Agresi Berganda

\begin{tabular}{|l|c|c|c|c|}
\hline \multirow{2}{*}{ Variabel } & Koefisien & & \multirow{2}{*}{ T } & Sig. \\
\cline { 2 - 4 } & $\mathrm{B}$ & $\begin{array}{c}\text { Std. } \\
\text { Error }\end{array}$ & & \\
\hline Konstanta & 3.610 & 1.044 & 3.457 & 0.001 \\
\hline Gaji & -0.084 & 0.152 & -0.554 & 0.076 \\
\hline $\begin{array}{l}\text { Jam kerja } \\
\text { fleksibel }\end{array}$ & -0.311 & 0.164 & -1.904 & 0.045 \\
\hline $\begin{array}{l}\text { Stres } \\
\text { kerja }\end{array}$ & 0.305 & 0.216 & 1.411 & 0.015 \\
\hline
\end{tabular}

Sumber: Hasil Output SPSS 25

Berdasarkan table 12 diatas, dapat dituliskan persamaan regresinya sebagai berikut: $\mathrm{Y} . \mathrm{KK}=3.610$ $+-0.084 \mathrm{G}+-0.311 \mathrm{JKF}+0.305 \mathrm{SK}+$ e. Uji statistik $\mathrm{t}$ model dilakukan untuk mengetahui pengaruh 
variabel independen (gaji, jam kerja fleksibel dan stres kerja) terhadap variabel dependen secara parsial. Berdasarkan tabel $4.13 \mathrm{di}$ atas, maka diperoleh hasil sebagai berikut:

a. Hasil uji t gaji diperoleh thitung sebesar -0.554 dengan nilai signifikan sebesar 0.076. Nilai signifikan tersebut lebih besar dari 0,05 sehingga dapat disimpulkan bahwa hipotesis antara gaji terhadap kinerja karyawan tidak terdukung.

b. Hasil uji $t$ jam kerja fleksibel diperoleh $t$ hitung sebesar 1.411 dengan nilai signifikan sebesar 0.015 . Nilai signifikan tersebut lebih kecil dari 0,05 sehingga dapat disimpulkan bahwa hipotesis antara Jam kerja fleksibel terhadap kinerja karyawan telah terdukung.

c. Hasil uji t stres kerja diperoleh thitung sebesar -1.904 dengan nilai signifikan sebesar 0.045 . Nilai signifikan tersebut lebih kecil dari 0,05 sehingga dapat disimpulkan bahwa hipotesis antara stres kerja terhadap kinerja karyawan telah terdukung.

\section{Kesimpulan}

Berdasarkan hasil penelitian diatas mengenai pengaruh gaji, jam kerja fleksibel dan stres kerja terhadap kinerja karyawan pada perusahaan yang berada di Kawasan Batamindo Industrial Park, Muka Kuning di Kota Batam. Kesimpulan yang dapat ditarik sebagai berikut:

1. Gaji tidak berpengaruh secara langsung terhadap kinerja karyawan. Hal ini menjelaskan jika gaji, tidak lagi menjadi faktor utama bagi karyawan perusahaan kawasan batamindo dalam meningkatkan kinerjanya. Hal ini menjelaskan jika pembayaran gaji dilakukan setiap bulan sekali dan sudah ditentukan jumlahnya oleh perusahaan dan dipasti dibayar, sehingga karyawan menganggap bahwa gaji merupakan sesuatu yang pasti dan tidak akan berkurang atau bertambah karena sudah ditentukan sebelumnya oleh perusahaan, maka karyawan menganggap bahwa bekerja secara maksimal atau tidak maksimal gaji tetap akan sama.

2. Jam kerja fleksibel berpengaruh negatif signifikan terhadap kinerja karyawan. Hal ini berarti implementasi jam kerja fleksibel yang diberikan oleh perusahaan terhadap karyawan, kurang memberikan manfaat yang baik bagi perusahaan.

3. Stres kerja berpengaruh positif signifikan terhadap kinerja karyawan secara langsung. Hal ini berarti stres kerja tidak hanya dapat memberikan efek negatif namun juga positif dalam membantu meningkatkan kinerja karyawan.

\section{Keterbatasan dan Saran}

Berdasarkan penelitian yang dilakukan, peneliti menyampaikan beberapa saran sebagai berikut:

1. Penelitian selanjutnya disarankan menambahkan variabel dengan faktor- faktor yang memengaruhi kinerja lainnya seperti, lingkungan kerja, gaya kepemimpinan atasan dan peran ambiguitas.

2. Penggunaan instrumen tidak hanya berupa kuesioner, juga bisa dilakukan wawancara secara langsung dengan narasumber, agar hasil yang didapat lebih akurat.

3. Penelitian selanjutnya disarankan untuk menggunakan sampel dari jenis perusahaan perusahaan yang berbeda.

Dalam penelitian ini, peneliti menemukan beberapa keterbatasan sebagai berikut:

1. Peneliti tidak mengawasi secara langsung beberapa pengisian kuesioner, sehingga kemungkinan jawaban yang tidak sesuai dengan realita di lapangan.

2. Sampel pada penelitian ini hanya terbatas pada karyawan perusahaan yang berada di Kawasan Batamindo Industrial Park, Muka Kuning di Kota Batam sehingga mungkin ada perbedaan hasil apabila menggunakan data seluruh perusahaan yang ada di Kota Batam. 


\section{Daftar Pustaka}

Abid, Sabiha , and Daro Khan Barech. 2017. "THE IMPACT OF FLEXIBLE WORKING HOURS ON THE EMPLOYEES PERFORMANCE." International Journal of Economics, Commerce and Management V (7): 450-466.

Ahmad, Abd Rahman, Mohammad Talha Mohamed Idris, and Mohd Hilmi Hashim. 2013. "A Study of Flexible Working Hours and Motivation.” (Canadian Center of Science and Education) IX (3): 208=215.

Chandhok, Anil , and Mansi Monga. 2013. “IMPACT OF JOB STRESS ON EMPLOYEE'S PERFORMANCE OF SALES DEPARTMENT: A COMPARATIVE STUDY OF LIC AND BAJAJ ALLIANZ LIFE INSURANCE COMPANY LTD IN THE SELECTED CITIES OF HARYANA." International Journal of Management Research and Business Strategy II (1): 63-70.

Deshpande, Revati C. 2012. "A healthy way to handle work place stress through Yoga, Meditation and Soothing Humor." INTERNATIONAL JOURNAL OF ENVIRONMENTAL SCIENCES II (IV): 2143-2154.

Fynes, N, and A Storrie. 1998. "Families and Work in the Twenty-first Century: Employer Benefit from Flexible Working." Department of Social and Family Affair.

Gharib, Moaz , Suhail Mohammad Ghouse, Moinuddin Ahmad, and Syed Ahsan Jamil. 2006. "The impact of job stress on job performance: A case study on academic staff at dhofar university." International Journal of Economic Research 13 (1): 21-33.

Ghozali, Imam. 2012. Aplikasi Multivariate dengan Program IBM SPSS 20. Semarang: Badan Penerbit Universitas Diponegoro.

Greenhaus, Jeffrey H, and Nicholas J Beutell . 1985. "Sources of conflict between work and family roles.” (Academy of Management Review) X (1): $76-88$.

Gunawan, Hendra, and Rezki Amalia. 2015. "Wages and Employees Performance: The Quality of Work Life as Moderator." International Journal of Economics and Financial Issues 5 (Special Issue): 349-353.

Hameed, Abdul, Muhammad Ramzan, Hafiz M. Kashif Zubair, Ghazanfar Ali, and Muhammad Arslan. 2014. "Impact of Compensation on Employee Performance (Empirical Evidence from Banking Sector of Pakistan).” International Journal of Business and Social Science 5 (2): 302-309.

Hartono, Jogiyanto. 2014. Metodologi Penelitian Bisnis Salah Kaprah dan Pengalaman-Pengalaman. 6. Yogyakarta: BPFE Yogyakarta.

Hashim, Muhammad , Mehboob Ullah, and Muhammad Azizullah Khan. 2017. "IMPACT OF TIME FLEXIBILITY ON EMPLOYEES' PERFORMANCE: A STUDY OF TEACHING FACULTY IN GOVERNMENT COLLEGES OF MANAGEMENT SCIENCES PESHAWAR." City University Research Journal (Special Issue: AIC): 206-212. 
Heider, Fritz. 1958. "The psychology of Interpersonal Relations." Wiley.

Hooks, K L, Thomas P, and L Higgs J. 2000. "Changing Environmental Productivity Relathionship in Profesional service Firm." (Working Paper, Floridina Atlantic University).

IAI. 2007. Standar Akuntansi Keuangan. Jakarta: Salemba 4.

Idris, M. 2011. "Over time effects of role stress on psychological strain among Malaysian Public University Academics." International Journal of Business and Social Science IV (1): 44-48.

Jones, Karen , and Edward Jones. 2011. "Flexible Working Practices in the UK: Gender and Management Perspectives." Journal of Women in Society II: 1-8.

Kattenbach, Ralph ， Evangelia Demerouti, and Friedhelm Nachreiner. 2012. "Flexible working times: effects on employees' exhaustion, work-nonwork conflict and job performance." Emerald Article XV (III): 279 $-295$.

Kelil, Ahmed. 2010. 'Employees' Perception towards Compensation and Benefit Policy: The case of some selected Government Higher Eduction Instituions in Addis Ababa."1-71.

Khuong , Mai Ngoc, and Vu Hai Yen. 2016. "Investigate the Effects of Job Stress on Employee Job Performance - A Case Study at Dong Xuyen Industrial Zone, Vietnam." International Journal of Trade, Economics and Finance 7 (2): 31-37.
Kotteeswari, M, and Tameem Sharief. 2014. “JOB

STRESS AND ITS IMPACT ON EMPLOYEES' PERFORMANCE A STUDY WITH REFERENCE TO EMPLOYEES WORKING IN BPOS.”International Journal of Business and Administration Research Review 2 (4): 18-25.

Luthans, Fred. 1988. “Organizational Behavior.” (Mc. Graw Hill) VIII.

Luthans, Fred. 2006. "Perilaku Organisasi.” (Penerbit Andi) X.

Luthans, Fred. 2013. "Organizational behavior: an evidence based approach.” (McGraw Hill).

Mangkunegara, Anwar Prabu . 2013. "Manajemen Sumber Daya Manusia perusahaan.” (PT Remaja Rosadakarya) (11): 67.

Mathis, Robert L, and Jhon H Jackson. 2006. "Manajemen Sumber Daya Manusia Perusahaan.” PT Salemba Empat.

McNall, Laurel A, Aline D Masuda, and Jessica M Nicklin. 2010. "Flexible Work Arrangements, Job Satisfaction, and Turnover Intentions: The Mediating Role of Work-to-Family Enrichment." The Journal of Psychology CXLIV (1): 61-81.

Mulyadi. 2013. "Sistem Akuntansi." Edited by Salemba Empat. III (4)

Muse, Lori, Stanley G Harris, William F Giles, and H S Field. 2008. "Work-Life Benefits and Positive Organizational Behavior: Is There a Connection?" Journal of Organizational Behavior XXIX: 171-192. 
Niosh. 1999. "Stress at Work." National Institute for Occupational Safety and Health 99-101.

Orpen, Christopher . 1981. “ Effect of Flexible Working Hours on Employee Satisfaction and Performance: A Field Experiment.” Journal of Applied Psychology 66 (1): 113-115.

Pujiastuti. 2013. "PENGARUH PENGHARGAAN, STRES KERJA DAN JENIS JAM KERJA TERHADAP KINERJA KARYAWAN."

Robbins, Stephen. 2006. "Perilaku Organisasi." (Prentice Hall) X.

Santoso, Purbayu Budi, and Ashari. 2005. "Analisis statistik dengan microsoft excel dan spss."

Sasono. 2004. "Mengelola Stres Kerja.” Jurnal Fokus Ekonomi III (2).

Shahzadi, Irum, Ayesha Javed, Syed Shahzaib Pirzada, Shagufta Nasreen, and Farida Khanam. 2014. "Impact of Employee Motivation on Employee Performance." European Journal of Business and Management VI (23): 159-167.

Stoner, James A.F., and Charles Wankel. 1988. “Manajemen." (CV. Intermedia Jakarta) III.

Su'ud, Hassan. 2007. "Manajemen Sumber Daya Manusia." V.

Sugiyono. 2010. "Metode Penelitian Pendidikan Pendekatan Kuantitatif, kualitatif, dan R\&D."

Veithzal, Rivai. 2004. "Manajemen Sumber Daya Manusia Untuk Perusahaan.” (PT. Raja GrafindoPersada) I.

Vroom, Victor H. 1964. "work and motivation.” (John Wiley and Sons, Inc).
Widiyanto, Ibnu. 2008. "Poiters Metodologi Penelitian Penerbit." CV Dikalia.

Zafar, Qadoos . 2015. "The Influence of Job Stress on Employees Performance in Pakistan." American Journal of Social Science Research I (4): $221-225$ 